\title{
Assessing riveted connections to Eurocode 3
}

1 Dave Gent BSC (Hons), CEng, MICE

Principal Engineer, Atkins, Derby, UK (corresponding author: dave.gent@atkinsglobal.com) (Orcid:0000-0002-8616-5580)
2. Anton lanakiev $\mathrm{PhD}$

Reader in Finite Element Modelling, Civil Engineering Department, School of Architecture, Design and Built Environment, Nottingham Trent University, Nottingham, UK (Orcid:0000-0002-1413-8110)
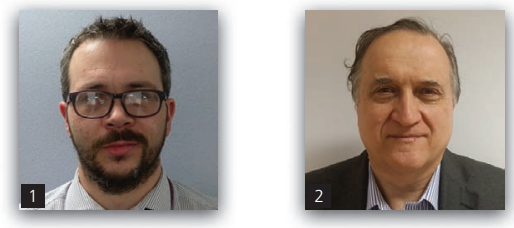

The focus of this paper is the assessment of wrought iron and early steel riveted connections in the future, with recommendations as to how different codes currently deal with the assessment and what may change if alternative codes are adopted. As British standards are being replaced by Eurocodes for design, it is inevitable that assessment codes of practice based on British standards will be replaced by those based on Eurocodes. This progression will ensure that future structures are designed and assessed using codes based on similar philosophies. However, this will also lead to older structures designed according to older codes based on different philosophies and constructed of materials not covered by the Eurocodes also being assessed according to Eurocode-based assessment codes. A similar situation already exists with structures being assessed using British standard-based assessment codes, which were written for the design of steel structures. This has resulted in the leading asset-owning organisations, such as Network Rail and Highways England, including guidance on adapting calculations to account for different material types.

\section{Introduction}

\subsection{The history of riveted connections}

Connections are only as strong as their parent material, and therefore both the physical connection (such as a bolt or rivet) and the members they are connecting should be considered when assessing the strength of a connection.

Rivets are permanent mechanical fasteners predominantly found on wrought iron and early steel structures. A rivet consists of a smooth cylindrical shaft with a 'head' at one end, with the opposite end known as the 'tail end'. Historical rivets were placed in a punched or drilled hole through two or more plates and the tail was deformed to create another head, sandwiching the plates together.

At the peak of their use in the nineteenth and early twentieth centuries, fabricating riveted structures was very labour intensive, with the rivets being hammered into position manually. It is understood that riveting was generally undertaken in the fabrication shop as opposed to on-site. Figure 1 shows typical rivet design data, given in Molesworth's Pocket Book of Engineering Formulce (Molesworth, 1862).

The use of riveted connections rose and fell correspondingly with the rise and fall in favour of wrought iron, approximately between 1830 and 1890 , but persisted as a favoured form of connection as early steel replaced wrought iron. Riveted connections appeared in all areas of fabrication, from shipbuilding to bridges, anywhere two or more plates required connecting, until they were slowly phased out by bolted connections, which required less physical effort to install and were less likely to damage the structure during installation or removal.

It is important to understand the difference between riveted and bolted connections. When a rivet was driven into position, it expanded to fill the hole completely and therefore removed the potential for slip, in contrast to modern bolted connections, which are provided with a 2 or $3 \mathrm{~mm}$ clearance and therefore the potential to slip remains. Because of this, riveted connections can be considered as rigid, whereas bolted connections cannot be.

It is important to consider that riveted connections tended to be designed in terms of a percentage of the strength of the connected members (i.e. 2 No. rivets equalled the shear strength of the angle section that they were connecting) rather than attempting to vary the capacity to match the theoretical strength requirement, as in modern design (i.e. the force applied equals $\mathrm{X}$ so 3 No. rivets are required). Figure 2 shows a typical fabricated bridge girder.

As a result, the riveting patterns in any given member tend to be uniform across the structure, rather than varying according to the stress variations in those members; therefore, the factor of safety on any given riveted connection is likely to vary considerably across the structure. It is therefore very important that the engineer take particular care when assessing those connections that are most heavily stressed, where the factor of safety is likely to be lowest.

It is also important to understand that the connection detail may be dictated by the yield stress of the members which are 


\section{Offprint provided courtesy of www.icevirtuallibrary.com Author copy for personal use, not for distribution}

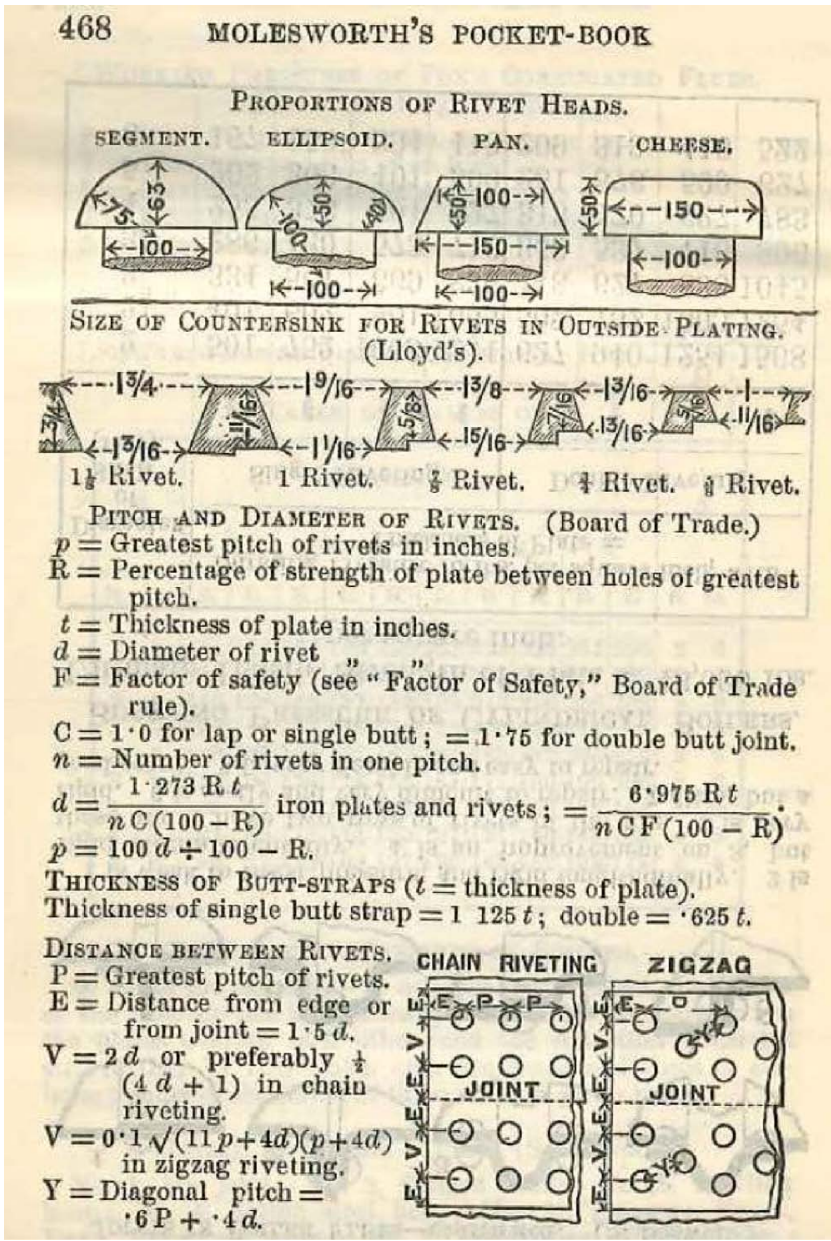

Figure 1. Extract from Molesworth's Pocket Book (Molesworth, 1862)

connected rather than that of the rivets forming the connection; therefore, both elements should be assessed.

\subsection{The problem}

The compliance date for all parts of Eurocode 1993 in the UK was March 2010. As British standards are replaced by Eurocodes for design, it is inevitable that assessment codes of practice based on British standards will be replaced by assessment codes based on the respective Eurocodes. This progression will ensure that future structures are designed and assessed using codes based on similar philosophies.

This progression in assessment procedure will lead to older structures designed according to older codes based on different philosophies and constructed of materials not covered by the Eurocodes also being assessed according to Eurocode-based assessment codes. A similar situation already exists with structures being assessed using British standard-based assessment codes, which were written for the design of steel structures. This has resulted in the leading asset-owning organisations, such as

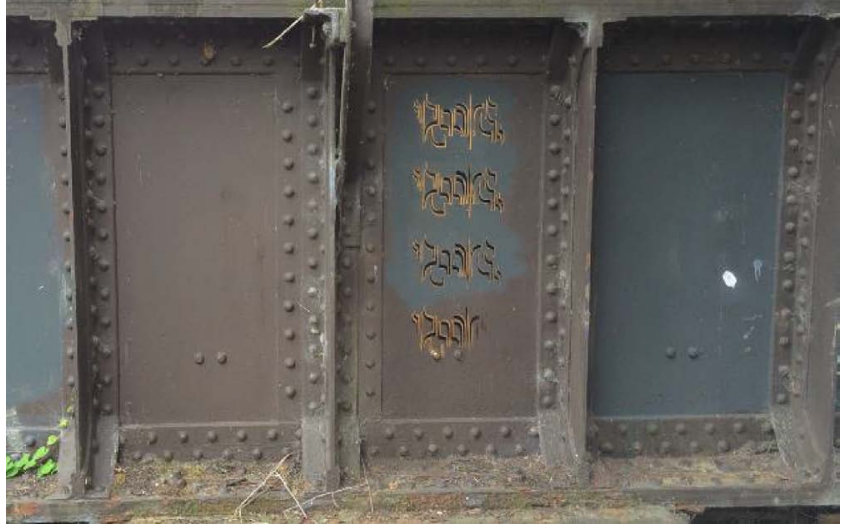

Figure 2. Typical fabricated wrought iron plate girder with riveted connections

Network Rail (NR) and Highways England, including guidance on adapting the calculations to account for different material types.

The Eurocodes are commonly accepted as having greater economy in design capacities than previous codes of practice (Hendy et al., 2011), being based on more recent design techniques and testing data. Currently there are no assessment codes based on Eurocodes, which means that existing structures are essentially being assessed using superseded techniques and test data, potentially missing out on any benefits which could be brought by applying the latest industry best practice.

The consequences of not taking advantage of this economy could result in unnecessary repairs, intervention to historic structures and disruption of infrastructure.

On a related note, the Eurocodes also specify and provide guidance for the use of advanced design tools such as finiteelement analysis, but current assessment codes do not provide adequate inputs, in terms of material properties, for example, to enable the assessment engineer to utilise these tools correctly or to their full potential. These inputs will be required in the future; however, this aspect of the requirements is not covered in great detail in this paper.

Adopting Eurocodes for use in assessment is likely, as with current assessment standards, to require modifications made to the base calculations in order to make them suitable for assessment rather than design as a result of several issues.

- Design standards assume as-built conditions with no allowance for the age and condition of the element under consideration, which will likely have an effect on the assessed capacity.

- The Eurocodes assume that structures are constructed with modern, measured material properties and to a particular level 


\section{Offprint provided courtesy of www.icevirtuallibrary.com} Author copy for personal use, not for distribution

of workmanship, which is unlikely to be the same as those for existing structures built according to a different set of standards and, particularly with wrought iron structures, with ambiguous material properties and varying qualities of workmanship.

- BS EN 1993-1-8:2005, 'Design of joints' (BSI, 2005a), includes steel rivets and assumes modern steel material properties. The majority of existing riveted structures are constructed of wrought iron and early steel; therefore, the calculations involved will not be entirely suitable in their current form.

- The way in which safety factors are applied varies between Eurocodes and the current assessment standards. Eurocodes are based on more recent testing techniques and results data than those for older codes, which will have an effect on the assessed capacity of structures designed to previous standards.

\subsection{The aim of this paper}

The focus of this paper is on the assessment of wrought iron and early steel riveted connections in accordance with Eurocode codes of practice. Connections are critical to a structure's integrity and it is often difficult to remove an adequate sample of rivets for testing due to both the large number present in historic platefabricated structures and the destructive nature of removing rivets. Therefore, it is essential that accurate and informed assessment, using the most up-to-date testing information, is undertaken to determine their capacity.

This paper compares the assessment of riveted connections based on BS EN 1993-1-8:2005 against the current assessment codes based on BS 5400-3:2000, 'Code of practice for design of steel bridges' (BSI, 2000), specifically looking at how the issues detailed in Section 2.1 can affect the assessment results.

Fatigue loading of structures, particularly historic structures, is a complex subject area in its own right and is therefore not covered by this paper. Refer to the investigations carried out by Taras and Greiner (2010) and Brühwiler et al. (2013).

\subsection{Summary of contributions}

- Section 2 gives a comparison of assessing capacity according to different standards.

- Section 3 gives a comparison of assessment results and makes recommendations.

\section{Comparison of assessment philosophies}

\subsection{Materials and testing}

In order to design rivets by using Eurocode 3 (EC3), it is assumed that the material is of 'as-fabricated' condition and that the yield strength of the material is known. Therefore, it is logical that in order to assess riveted connections in accordance to EC3, it is crucial that the yield stress and condition of the material being assessed is known and accounted for correctly.
The most accurate way of determining the condition and dimensions is by inspection and measurement. Determining the correct material properties for use in assessment can be achieved in two ways

- testing

- using empirical data.

Due to inconsistencies in materials and workmanship, age and condition, determining the material properties of rivets requires that an adequate sample size be tested. For structures constructed of fabricated members, the cost and difficulties associated with testing even $5 \%$ of the total number of rivets within the structure would be prohibitive. Additionally, many of the rivets present may not be original, due to replacement and repair over a period of 100 years or more, and may be significantly damaged during the removal process - factors which would all require the sample size to increase.

It can therefore be concluded that testing an adequate number of riveted connections from every structure that requires assessment is impractical, which leads to the use of empirical data.

This results in a more economical approach to determining material properties from empirical data. The material properties given in BD21/01, 'The assessment of highway bridges and structures' (HA, 2001), are based on data gathered preceding the publication of the document in 2001. Similarly, the values given in NR/GN/CIV/025, 'Structural assessment of underbridges' (NR, 2006), are based on data gathered preceding the publication of the document in 2006.

Additionally, both documents give a single value for yield stress per material type, which does not fully reflect the variety of material strengths present in existing structures. For example, wrought iron was used as a principal construction material throughout the 1800s; therefore, using a single yield stress value based on worst-case testing does not lend itself to the complex assessment tools which are now available. BD21/01 gives a yield stress of $220 \mathrm{~N} / \mathrm{mm}^{2}, \mathrm{NR} / \mathrm{GN} / \mathrm{CIV} / 025$ gives $190 \mathrm{~N} / \mathrm{mm}^{2}$ and for comparison the Historical Structural Steelwork Handbook (Bates, 1990) gives an ultimate tensile strength of $21 \mathrm{t} / \mathrm{inch}^{2}$ (approximately $290 \mathrm{~N} / \mathrm{mm}^{2}$, with a yield stress of $175 \mathrm{~N} / \mathrm{mm}^{2}$ ), showing the diverse range of yield stresses based on empirical data that are currently available.

The process of carrying out an assessment of riveted connections by using EC3 would be very similar to the current methods used; dimensional information would be taken from available record information, backed up and verified with the latest site inspection data, followed by numerical assessment.

In the years since the mentioned documents were published, further material tests will have been undertaken using more advanced testing techniques; therefore, it is imperative that if 


\section{Offprint provided courtesy of www.icevirtuallibrary.com Author copy for personal use, not for distribution}

nothing else, the material properties used to assess riveted connections according to EC3 should reflect more recent assessment results, pull together knowledge from across different sectors and not be limited to single, worst-case values.

\subsection{Current industry practice}

Looking at the assessment of bridge structures, and focusing on the assessment of wrought iron rivets for the purposes of comparison, there are currently two main assessment codes of practice in common use: the Highways Agency (HA) standard BD21/01, governing the assessment of highway bridges, and the NR standard NR/GN/CIV/025, covering the assessment of railway bridges, both of which are based on the superseded British standard BS 5400-3:2000.

BS 5400-3:2000 details the methods for designing riveted connections, essentially dividing the applied forces over the crosssectional area of the rivet shank and comparing the result against the yield stress of the material with the application of partial safety factors.

For the purposes of assessing elements, BS 5400-3:2000 is modified by the following documents.

BD21/01 is published by Highways England and states that wrought iron should be treated in a manner similar to that done for steel and therefore should be assessed in accordance with the HA's code of practice BD56/10, 'The assessment of steel highway bridges and structures' (HA, 2010).

The yield stress of wrought iron is given in BD21/01, annex C of the document (HA, 2001), stating that 'As a general guide the characteristic yield stress [of wrought iron] may be taken as $220 \mathrm{~N} / \mathrm{mm}^{2}$, and that testing should be carried out where defects are present. The document then later contradicts this slightly by stating that testing is expensive and should be avoided and that it is "unlikely that a few test results will provide any more reliable information about the yield stress of the material in the structure as a whole than $\left[220 \mathrm{~N} / \mathrm{mm}^{2}\right]$, which is based on a large number of tests' (HA, 2001).

BD56/10 is based on the superseded British standard BS 5400$3: 2000$. The current version published in 2010 provides supplementary guidance on using BS 5400 Part 3-3:2000 for the assessment of structures. There are no specific references to the assessment of wrought iron, resulting in both steel and wrought iron being assessed in the same way with only the guidance in BD21/01 differentiating between them.

$\mathrm{NR} / \mathrm{GN} / \mathrm{CIV} / 025$ is NR's equivalent of BD21/01 and BD56/10 combined into one document and again provides supplementary guidance on the assessment of riveted connections based on BS 5400-3:2000, although less guidance is given specifically for the assessment of riveted connections. However, NR/GN/CIV/025 gives a guideline yield stress of wrought iron rivets as $250 \mathrm{~N} / \mathrm{mm}^{2}$, greater than that given by BD21/01, and greater partial safety factors in some cases, which would suggest that capacities would be different from those calculated using BD21/01.

Compare these assessment codes with the current design code for steel connections.

BS EN 1993-1-8:2005, 'Design of joints', is the Eurocode document which covers the assessment of connections, supplemented by BS EN 1993-1-1:2005+A1:2014, 'General rules and rules for buildings' (BSI, 2005b), and BS EN 1993-2:2006, 'Steel bridges' (BSI, 2006) and the relevant National Annex documents for each part.

BS EN 1993-1-8:2005 covers the design of rivets and bolts with the same set of calculations, calculating the capacities in a way similar to what BS 5400-3:2000 does, with reference to BS EN 1993-2:2006 for material factors.

The calculation for shear and tension resistances are the same for rivets, assuming no variation in the way in which the material behaves in different situations.

For the purposes of comparison, this paper looks specifically at the assessment of shear and tension capacity. Refer to Table 1 for a comparison of the philosophies used by the different codes of practice.

\subsection{Applying EC3 to the assessment of riveted connections}

Table 2 is a comparison of the assessment results in accordance to each of the standards using the input detailed in Table 1.

Where the British standards and Eurocodes do not specify a yield stress for wrought iron, calculations using both 220 and $250 \mathrm{~N} / \mathrm{mm}^{2}$ have been undertaken for comparison.

The assessment is based on a single rivet with a shank diameter of $18.75 \mathrm{~mm}$, connecting $2 \mathrm{No}$. $12.5 \mathrm{~mm}$ thick wrought iron plates, therefore assuming a single shear plane (as shown in Figure 3).

It can be seen from the comparison in Table 2 that EC3 gives an approximately $5 \%$ increase in the axial capacity compared with BS 5400-3:2000 and up to $30 \%$ increase in the shear capacity. This is similar to other comparison calculations that have been undertaken to inform this paper, comparing different sections of the Eurocodes against the current assessment codes, which provided an average of $29 \%$ increase in calculated capacity.

Although BS 5400-3:2000 is now superseded for design, the method of calculating the assessed capacity of riveted connections is based on first principles and is therefore comparable to the design methods used in EC3 and able to inform the conversion of EC3 for use in assessment. The equation is essentially the same, 


\section{Offprint provided courtesy of www.icevirtuallibrary.com Author copy for personal use, not for distribution}

Table 1. Comparison of design/assessment philosophies

\begin{tabular}{|c|c|c|c|c|}
\hline & BS $5400-3: 2000$ & BD56/10 & NR/GN/CIV/025 & EC3 \\
\hline $\begin{array}{l}\text { Yield } \\
\text { strength }\end{array}$ & N/A & $220 \mathrm{~N} / \mathrm{mm}^{2}$ & $250 \mathrm{~N} / \mathrm{mm}^{2}$ & N/A \\
\hline $\begin{array}{l}\text { Partial } \\
\text { safety } \\
\text { factors }\end{array}$ & $\begin{array}{l}\text { Cl. } 4.3 .3 \text {, Table } 2 \\
\text { Material factors } \\
\gamma_{m}=1 \cdot 20 \text { for fasteners in tension } \\
\gamma_{m}=1 \cdot 10 \text { for fasteners in shear } \\
\text { Accuracy factors } \\
\gamma_{43}=1 \cdot 10 \text { for ULS }\end{array}$ & $\begin{array}{l}\text { Cl. } 4.3 .3 \\
\text { Material factors } \\
\gamma_{m}=1.20 \text { for wrought iron } \\
\text { unless material testing is } \\
\text { undertaken, in which case, } \\
\text { there is a formula given for } \\
\text { determining } \gamma_{m} \\
\text { Accuracy factors } \\
\gamma_{+3}=1 \cdot 10 \text { for ULS (from } \\
\text { BD21/01) }\end{array}$ & $\begin{array}{l}\text { Material factors } \\
\gamma_{m}=1.20 \text { for fasteners in tension } \\
\gamma_{m}=1.10 \text { for web/flange rivets in } \\
\text { shear } \\
\gamma_{m}=1.33 \text { for all other rivets } \\
\text { Accuracy factors } \\
\gamma_{43}=1.10 \text { for ULS }\end{array}$ & $\gamma_{\mathrm{M} 2}=1 \cdot 25$ \\
\hline $\begin{array}{l}\text { Minimum } \\
\text { pitch }\end{array}$ & 2.5 times shank diameter & $\begin{array}{l}2.5 \text { times shank diameter } \\
\text { With guidance on reducing the } \\
\text { capacity if the distance is less } \\
\text { than this }\end{array}$ & 2.5 times shank diameter & $2 \cdot 2$ times shank diameter \\
\hline $\begin{array}{l}\text { Edge } \\
\text { distance }\end{array}$ & $1 \cdot 2$ times hole diameter & $\begin{array}{l}1 \cdot 2 \text { times hole diameter } \\
\text { With guidance on reducing the } \\
\text { capacity if the distance is less } \\
\text { than this }\end{array}$ & $\begin{array}{l}1.2 \text { times hole diameter } \\
\text { With guidance on reducing the } \\
\text { capacity if the distance is less } \\
\text { than this relative to the pitch of } \\
\text { connections }\end{array}$ & $1 \cdot 2$ times hole diameter \\
\hline $\begin{array}{l}\text { Axial } \\
\text { tension }\end{array}$ & $\begin{array}{l}\text { Cl. 14.5.3.3: Rivets in axial } \\
\text { tension } \\
\qquad \sigma=\frac{P_{\mathrm{t}}+H}{A_{\mathrm{er}}}<\frac{\sigma_{\mathrm{t}}}{\gamma_{\mathrm{m}} \gamma_{\mathrm{f3}}} \\
\text { Tension + prying force/rivet } \\
\text { hole area } \\
\text { Less than } 0.8 \times \text { yield stress/ } \\
\text { partial factors } \\
\text { Essentially force over area, } \\
\text { reducing the yield stress by } \\
20 \% \text {, allowing for hole } \\
\text { clearances }\end{array}$ & $\begin{array}{l}\text { Cl. 14.5.3.3: Rivets in axial } \\
\text { tension } \\
\text { As per BS 5400-3:2000, taking } \\
\text { into account site observations: } \\
\text { 'The tensile capacity must be } \\
\text { reduced where there is } \\
\text { significant loss of rivet heads' } \\
\text { (BSI, 2000) }\end{array}$ & $\begin{array}{l}\text { Cl. 14.5.3.3A: Rivets in axial } \\
\text { tension } \\
\text { As per BS 5400-3:2000, taking } \\
\text { into account site observations: } \\
\text { 'The tensile capacity must be } \\
\text { reduced where there is } \\
\text { significant loss of rivet heads' } \\
\text { (BSI, 2000) as per BD21/01. }\end{array}$ & $\begin{array}{l}\text { Table } 3.4 \\
\qquad F_{\mathrm{v}, \mathrm{Rd}}=\frac{0.6 f_{\mathrm{ur}} A_{0}}{\gamma_{\mathrm{M} 2}} \\
\text { This equates to } 60 \% \text { of } \\
\text { the ultimate tensile } \\
\text { stress, which is then } \\
\text { further reduced by } \\
25 \% \text { by the material } \\
\text { factor }\end{array}$ \\
\hline $\begin{array}{l}\text { Shear } \\
\text { resistance }\end{array}$ & $\begin{array}{l}\text { Cl. 14.5.3.4: Fasteners subject to } \\
\text { shear } \\
\qquad \tau=\frac{V}{n A_{\mathrm{eq}}}<\frac{\sigma_{\mathrm{q}}}{\gamma_{\mathrm{m}} \gamma_{\mathrm{f}} \sqrt{2}} \\
\text { Maximum shear stress is the } \\
\text { applied shear force applied over } \\
\text { the cross-sectional area of the } \\
\text { rivet shank, taking into account } \\
\text { the number of shear planes the } \\
\text { force is passing through } \\
\text { Less than 0.85× yield stress/partial } \\
\text { safety factors } \\
\text { Essentially force over area, } \\
\text { reducing the yield stress by } \\
15 \% \text {, allowing for hole } \\
\text { clearances }\end{array}$ & $\begin{array}{l}\text { As per BS } 5400-3: 2000, \text { no } \\
\text { supplementary advice given }\end{array}$ & $\begin{array}{l}\text { Less than } 0.90 \times \text { ultimate yield } \\
\text { strength/partial safety factors } \\
\text { Ultimate yield strength for } \\
\text { wrought iron given in } \\
\text { NR/GN/CIV/025 }=350 \mathrm{~N} / \mathrm{mm}^{2}\end{array}$ & $\begin{array}{l}\text { Table } 3.4 \\
\qquad F_{\mathrm{v}, \mathrm{Rd}}=\frac{0.6 f_{\mathrm{ur}} A_{0}}{\gamma_{\mathrm{M} 2}} \\
\text { This equates to } 60 \% \text { of } \\
\text { the ultimate tensile } \\
\text { stress, which is then } \\
\text { further reduced by } \\
25 \% \text { by the material } \\
\text { factor }\end{array}$ \\
\hline
\end{tabular}

N/A, not available; $\mathrm{Cl}$., clause

Table 2. Comparison of material properties from codes of practice

\begin{tabular}{|c|c|c|c|c|c|c|}
\hline & \multicolumn{2}{|c|}{ BS 5400-3:2000 } & \multirow{2}{*}{$\begin{array}{c}\text { BD56/10 } \\
220\end{array}$} & \multirow{2}{*}{$\begin{array}{c}\text { NR/GN/CIV/025 } \\
250\end{array}$} & \multicolumn{2}{|c|}{ EC3 } \\
\hline Yield stress: $\mathrm{N} / \mathrm{mm}^{2}$ & 220 & 250 & & & 220 & 250 \\
\hline Axial tension: $\mathrm{N} / \mathrm{mm}^{2}$ & 167 & 189 & 167 & 144 & 175 & 200 \\
\hline Shear resistance: $\mathrm{N} / \mathrm{mm}^{2}$ & 128 & 146 & 118 & 184 & 175 & 200 \\
\hline
\end{tabular}




\section{Offprint provided courtesy of www.icevirtuallibrary.com} Author copy for personal use, not for distribution

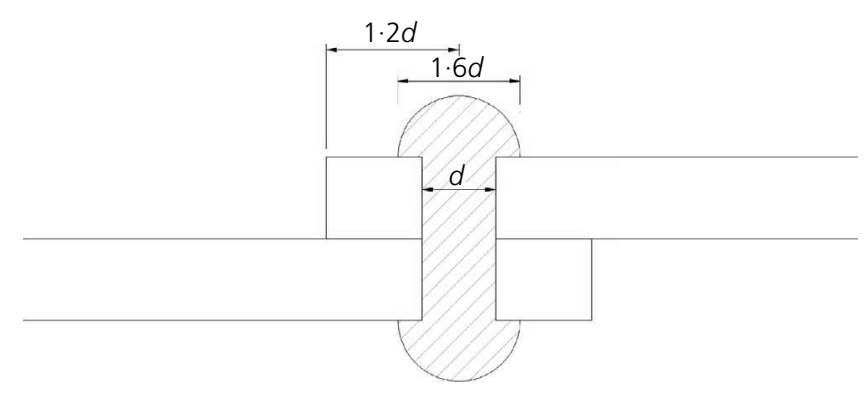

Figure 3. Typical rivet fixing arrangement

the difference being in the application of factors, with the Eurocodes assuming a higher construction tolerance and no difference between the ways in which the material behaves in tension or shear.

In terms of assessment, BS 5400-3:2000 gives approximately the same results as BD56/10 but lower shear results than those of NR/GN/CIV/025, which seems more favourable. This difference is because NR/GN/CIV/025 bases the shear capacity on the ultimate tensile strength rather than the yield stress and is therefore more comparable to $\mathrm{EC} 3$, which also uses the ultimate tensile stress.

\section{Summary}

\subsection{Conclusion}

EC3 gives more favourable results than any of the British standard-based codes. This is as a result of the code using the ultimate tensile strength rather than the yield stress and not applying an accuracy factor, only a material factor.

If EC3 were to be used for assessment, an accuracy factor would need to be applied in order to reflect the historic workmanship. Alternatively, a condition factor could be applied to reflect the age and condition of the structure and the fact that materials are unlikely to be in 'as-built' condition at the time of assessment.

Simply applying a $1 \cdot 1 \gamma_{\mathrm{f} 3}$ factor may give would give overconservative results and would therefore eliminate any economic benefits brought by the adoption of Eurocodes for assessment. In related research that has been undertaken on the topic of assessing wrought iron structures by using the Eurocodes, a $\gamma_{\mathrm{f3}}$ factor of 1.06 was determined to be the most suitable value, based on analysis of historical material testing data.

\section{REFERENCES}

Bates W (1990) Historical Structural Steelwork Handbook. The British Constructional Steelwork Association, UK.

Brühwiler E, Bosshard M, Steck P et al. (2013) Fatigue safety examination of a riveted railway bridge using data from long term monitoring. IABSE Symposium Report 99(25): 477-484.

BSI (2000) BS 5400-3:2000: Steel, concrete and composite bridges. Code of practice for design of steel bridges. BSI, London, UK.

BSI (2005a) BS EN 1991-1-8:2005: Eurocode 3. Design of steel structures. Design of joints. BSI, London, UK.

BSI (2005b) BS EN 1993-1-1:2005+A1:2014: Eurocode 3. Design of steel structures. General rules and rules for buildings. BSI, London, UK.

BSI (2006) BS EN 1993-2:2006: Eurocode 3. Design of steel structures. Steel bridges. BSI, London, UK.

HA (Highways Agency) (2001) BD21/01: The assessment of highway bridges and structures. The Stationery Office, London, UK.

HA (2010) BD56/10: The assessment of steel highway bridges and structures. The Stationery Office, London, UK.

Hendy CR, Sandberg J and Shetty NK (2011) Recommendations for assessment Eurocodes for bridges. Proceedings of the Institution of Civil Engineers - Bridge Engineering 164(1): 3-14, http://dx.doi.org/ 10.1680 /bren.900030.

Molesworth GL (1862) Molesworth's Pocket Book of Engineering Formulae. London, UK.

NR (Network Rail) (2006) NR/GN/CIV/025: The structural assessment of underbridges. NR, London, UK.

Taras A and Greiner R (2010) Development and application of a fatigue class catalogue for riveted bridge components, structural engineering international. Structural Engineering International 20(1): 91-103, http://dx.doi.org/10.2749/101686610791555810.

\section{How can you contribute?}

To discuss this paper, please email up to 500 words to the editor at journals@ice.org.uk. Your contribution will be forwarded to the author(s) for a reply and, if considered appropriate by the editorial board, it will be published as discussion in a future issue of the journal.

Proceedings journals rely entirely on contributions from the civil engineering profession (and allied disciplines).

Information about how to email your paper online is available at www.icevirtuallibrary.com/page/authors, where you will also find detailed author guidelines. 